Article

\title{
Synergistic In Vitro Antimicrobial Activity of Triton X-100 and Metformin against Enterococcus faecalis in Normal and High-Glucose Conditions
}

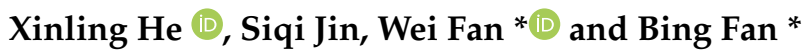 \\ The State Key Laboratory Breeding Base of Basic Science of Stomatology (Hubei-MOST) and Key Laboratory of \\ Oral Biomedicine Ministry of Education, School and Hospital of Stomatology, Wuhan University, \\ Wuhan 430079, China; 2014302220020@whu.edu.cn (X.H.); 2018303042023@whu.edu.cn (S.J.) \\ * Correspondence: weifan@whu.edu.cn (W.F.); bingfan@whu.edu.cn (B.F.); Tel.: +86-27-8768-6210 (W.F.)
}

check for updates

Citation: He, X.; Jin, S.; Fan, W.; Fan, B. Synergistic In Vitro Antimicrobial Activity of Triton X-100 and Metformin against Enterococcus faecalis in Normal and High-Glucose Conditions. Microorganisms 2022, 10, 124. https://doi.org/10.3390/ microorganisms10010124

Academic Editors: Elisabeth Grohmann and Miguel Viñas

Received: 2 December 2021

Accepted: 5 January 2022

Published: 7 January 2022

Publisher's Note: MDPI stays neutral with regard to jurisdictional claims in published maps and institutional affiliations.

Copyright: (C) 2022 by the authors. Licensee MDPI, Basel, Switzerland. This article is an open access article distributed under the terms and conditions of the Creative Commons Attribution (CC BY) license (https:// creativecommons.org/licenses/by/ $4.0 /)$.

\begin{abstract}
The prevention and treatment of oral diseases is more difficult in diabetic patients with poorly controlled blood glucose levels. This study aims to explore an effective, low-cytotoxicity medication for root canal treatment in diabetic patients. The antibacterial effect of the combination of Triton X-100 (TX-100) and metformin (Met) on Enterococcus faecalis (E. faecalis) was evaluated by determining the minimum inhibitory concentration (MIC), minimum bactericidal concentration required to kill $99 \%$ bacteria $\left(\mathrm{MBC}_{99}\right)$ and by conducting dynamic time-killing assays. While the antibiofilm activity was measured by crystal violet (CV) assay, field emission scanning electron microscope (FE-SEM), confocal laser scanning microscope (CLSM) and colony-forming unit (CFU) counting assays. The expression of relative genes was evaluated by real-time quantitative polymerase chain reaction (RT-qPCR), and the cytotoxicity of the new combination on MC3T3-E1 cell was also tested. Results showed that the antibacterial and antibiofilm activities of Met could be significantly enhanced by very low concentrations of TX-100 in both normal and high-glucose conditions, with a much lower cytotoxicity than $2 \%$ chlorhexidine (CHX). Thus, the TX-100 + Met combination may be developed as a promising and effective root canal disinfectant for patients with diabetes.
\end{abstract}

Keywords: antimicrobial activity; dentinal tubules; Enterococcus faecalis; high-glucose condition; metformin; Triton X-100

\section{Introduction}

Enterococcus faecalis (E. faecalis), a Gram-positive facultative anaerobe, has been highly detected in refractory root canal infection and reinfection of human teeth [1-4]. As such, it has often been used to evaluate the antibacterial efficiency of various intracanal medications [5,6]. In diabetic patients, high blood glucose levels provide rich nutrients for bacteria to survive and proliferate in infected areas. Therefore, uncontrolled diabetes is associated with low oral health-related quality of life [7], with patients more likely to develop oral diseases [8-11]. The prevention and treatment of oral diseases in diabetic patients with poorly controlled blood glucose levels would be more difficult than in those with well-controlled blood glucose levels [12,13].

The curvatures and complex internal anatomical variations of the root canal system make it difficult for the chemomechanical preparation of root canal treatment to fully achieve the treatment goals [14]. In addition, it may be difficult for the disinfectant to reach the target lesion at a fully effective concentration, due to the narrow anatomical structure of the root. However, subinhibitory concentrations of antibiotics in the variant anatomy of the root canal may in turn induce increased biofilm formation ability and decreased antibiotic susceptibility of E. faecalis [15], and finally lead to the failure of endodontic therapy. Moreover, antibiotic resistance of many pathogenic bacteria is becoming a serious 
threat to clinical treatment and public health $[16,17]$. Therefore, non-antibiotic bactericidal agents have been the focus of research in recent decades.

Metformin (Met) is commonly used to treat type 2 diabetes mellitus [18-20]. It is generally believed that the metabolic regulatory effect of Met is related to the activation of adenosine monophosphate-activated protein kinase. By inhibiting complex I of the mitochondrial respiratory chain, Met further inhibits the production of adenosine triphosphate, thereby reducing gluconeogenesis [21,22]. As a clinical medicament, Met shows pleiotropic effects, such as direct inhibition of inflammation [22], protection of the cardiovascular system [23], and inhibition of tumor growth, in addition to its traditional effects on glucose metabolism [24,25]. As an antibacterial agent, Met has been shown to be effective against a wide range of microbes, including oral pathogens [21,26]. Khajuria et al. [27] demonstrated its inhibitory activity against Porphyromonas gingivalis and hence its effectiveness in the treatment of diabetes-related periodontitis. However, to date, no studies have investigated the inhibitory effect of Met on E. faecalis in root canal infections, especially in patients with diabetes.

Triton X-100 (TX-100), a non-ionic surfactant, is commonly used to increase the cell membrane permeability to antibodies but itself has only weak antibacterial activity [28,29]. Some studies have used TX-100 to modify nanomaterials so as to enhance their antibacterial effects $[28,30]$. Some researchers have combined TX-100 with other materials to obtain synergistic antimicrobial effects [31-33]. Komatsuzawa et al. [34] reported that TX-100 could alter the drug resistance of Staphylococcus aureus.

Based on the above information, the main objective of this study was to combine the non-ionic surfactant TX-100 and Met and investigate the synergistic antimicrobial effect of the new combination against $E$. faecalis in both normal and high-glucose conditions.

\section{Materials and Methods}

2.1. Antibacterial Activities of TX-100, Met, and TX-100 + Met against Planktonic E. faecalis

2.1.1. Minimum Inhibitory Concentration (MIC) and Minimum Bactericidal Concentration Required to Kill 99\% Bacteria (MBC 99 )

The MIC and $\mathrm{MBC}_{99}$ of TX-100 and Met were determined using a serial microdilution assay. Briefly, a series of two-fold dilutions of TX-100 (neoFroxx GmbH Co., Ltd., Einhausen, Germany) (ranging from $10.24 \%$ to $0.02 \%$ ) and a series of solutions of Metformin hydrochloride (Aladdin Industrial Corporation Co., Ltd., Shanghai, China) with a concentration interval of $40 \mathrm{mg} / \mathrm{mL}$ (ranging from 120 to $400 \mathrm{mg} / \mathrm{mL}$ ) were prepared in sterile double-distilled water. For the culture of E. faecalis, normal brain heart infusion (BHI) medium was used to simulate normal conditions, while BHI supplemented with glucose (final concentration is $25.5 \mathrm{mM}$ ) was used to simulate high-glucose conditions. Subsequently, $100 \mu \mathrm{L}$ suspension $\left[2 \times 10^{5}\right.$ colony-forming units $\left.(\mathrm{CFU}) / \mathrm{mL}\right]$ of E. faecalis (ATCC 29212, ATCC, Manassas, VA, USA) in BHI medium (normal and high-glucose) and $100 \mu \mathrm{L}$ of drug solution as described above were mixed in a 96-well plate, and then incubated in a humidified atmosphere of $5 \% \mathrm{CO}_{2}$ and $1 \% \mathrm{O}_{2}$ at $37^{\circ} \mathrm{C}$ (same for all the following E. faecalis experiments) for $24 \mathrm{~h}$. Untreated bacteria and BHI medium were used as blank and background controls, respectively. The absorbance at $600 \mathrm{~nm}$ was measured using a microplate reader (Power Wave XS2, BioTek Instruments, Winooski, VT, USA). The MIC was defined as the lowest concentration with no turbidity compared to the background control. The $\mathrm{MBC}_{99}$ was determined by inoculating the suspensions at concentrations equal to or higher than the MIC on a BHI agar plate. The lowest concentrations at which less than $1 \%$ of the initially inoculated colonies of the blank control were visible after incubation were regarded as $\mathrm{MBC}_{99}$. This test was repeated six times.

\subsubsection{Synergistic Antibacterial Activities of TX-100 and Met against E. faecalis}

The synergistic MIC and $\mathrm{MBC}_{99}$ of TX-100 and Met were determined using the method described above. In addition, $0.02 \%$ and $0.04 \%$ concentrations of TX-100 were selected as 
the final synergistic concentrations, and a series of Met solutions with final concentrations ranging from 10 to $90 \mathrm{mg} / \mathrm{mL}$ was prepared. This test was repeated six times.

\subsubsection{Dynamic Time-Killing Assays}

The bacterial dynamic time-killing assay was performed using the following method. Enterococcus faecalis in the exponential phase was diluted in BHI to obtain a concentration of $2 \times 10^{6} \mathrm{CFU} / \mathrm{mL}$. For the single-drug test, $0.04 \%$ TX-100 and $100 \mathrm{mg} / \mathrm{mL}$ Met were used. For the combination drug test, TX-100 (final concentrations were $0.02 \%$ and $0.04 \%$ ) and Met (final concentrations were 40,60,80, and $100 \mathrm{mg} / \mathrm{mL}$ ) were mixed in advance. Thereafter, $500 \mu \mathrm{L}$ aliquots of the solutions containing single or combination drugs at different concentrations were mixed with the same volume of the diluted bacterial suspension, followed by incubation at $37^{\circ} \mathrm{C}$. Chlorhexidine ( $\mathrm{CHX}, 2 \%$ ) (Adamas, Basel, Switzerland) was used as a positive control, and non-treated groups were used as blank controls. At 3, 6, 12, 24, 36 , and $48 \mathrm{~h}$, the samples were agitated using a vortex mixer (Zhongxi Yuanda Technology Co., Ltd. Beijing, China), and $10 \mu \mathrm{L}$ of the mixture was taken out and inoculated onto a $\mathrm{BHI}$ agar plate. After incubation at $37^{\circ} \mathrm{C}$ for $24 \mathrm{~h}$, the bacterial colonies of different groups were counted. The assays were performed six times.

\subsection{Antibiofilm Activities of TX-100, Met, and TX-100 + Met against E. faecalis Biofilm}

\subsubsection{Inhibition of Bacterial Attachment}

The effects of TX-100, Met, and their combinations on E. faecalis biofilm were determined using the following method. First, a series of final concentrations of Met solutions $(0.5 \times, 1 \times, 2 \times, 3 \times$, and $4 \times$ MIC) were prepared with or without TX-100 $(0.02 \%$ and $0.04 \%)$. Enterococcus faecalis treated with $\mathrm{BHI}$ medium was used as a blank control. Subsequently, $100 \mu \mathrm{L}$ of the test solution and $100 \mu \mathrm{L}$ of E. faecalis suspension $\left(2 \times 10^{8} \mathrm{CFU} / \mathrm{mL}\right)$ in BHI medium (normal and high-glucose) were mixed in a 96-well plate and incubated at $37{ }^{\circ} \mathrm{C}$ for $24 \mathrm{~h}$. The crystal violet (CV) assay was used to measure the biomass and metabolic activity of E. faecalis biofilms. Briefly, after incubation, the supernatant was discarded gently, and the biofilms were washed with phosphate-buffered saline (PBS) (pH 7.2) to remove unattached bacteria. After fixing with $200 \mu \mathrm{L}$ of anhydrous methanol for $15 \mathrm{~min}$, the biofilms were stained with $200 \mu \mathrm{L}$ of $0.1 \%$ CV for 15 min in the dark. The unbound CV was washed with PBS, and the biofilm-bound CV was dissolved in an additional $200 \mu \mathrm{L}$ of anhydrous methanol. A microplate reader was used to measure the absorbance of the bound CV at $560 \mathrm{~nm}$. The lowest concentration at which biofilm formation was inhibited by at least $50 \%$ compared to that of the blank control was determined as the minimum biofilm inhibition concentration $\left(\mathrm{MBIC}_{50}\right)$. The experiment was repeated six times.

\subsubsection{Biofilm Disruption Assay}

This assay was similar to that described above. Briefly, $200 \mu \mathrm{L}$ of E. faecalis suspension $\left(2 \times 10^{8} \mathrm{CFU} / \mathrm{mL}\right)$ in BHI medium (normal and high-glucose) was seeded into a 96-well plate and incubated at $37{ }^{\circ} \mathrm{C}$ for $72 \mathrm{~h}$ for biofilm formation. Subsequently, the supernatant was replaced with the test solutions prepared in BHI medium, followed by another $24 \mathrm{~h}$ of incubation for biofilm disruption. The absorbance of the biofilm-bound CV measured at $560 \mathrm{~nm}$ was used to evaluate the effect of the test solutions on the biofilm. The lowest concentration at which the formed biofilm was eradicated by at least $50 \%$ compared to the blank control was determined as the minimum biofilm reduction concentration $\left(\mathrm{MBRC}_{50}\right)$. The assay was repeated six times.

\subsection{Antimicrobial Effect against E. faecalis on Dentin}

Dentin slices $(4 \mathrm{~mm}$ wide $\times 4 \mathrm{~mm}$ long $\times 1 \mathrm{~mm}$ thick) were prepared from human extracted wisdom teeth. All dentin slices were ultrasonically rinsed for $4 \mathrm{~min}$ in doubledistilled water, $5.25 \%$ sodium hypochlorite $(\mathrm{NaClO})$, and $17 \%$ ethylenediaminetetraacetic acid (EDTA), and then again rinsed in double-distilled water for $1 \mathrm{~min}$. The dentin slices were autoclaved at $121^{\circ} \mathrm{C}$ for $20 \mathrm{~min}$ in double-distilled water and then incubated for $24 \mathrm{~h}$ 
in BHI at $37^{\circ} \mathrm{C}$ to ensure aseptic conditions. Sterilized dentin slices were soaked in $1 \mathrm{~mL}$ of E. faecalis suspension $\left(1 \times 10^{8} \mathrm{CFU} / \mathrm{mL}\right)$ in BHI medium (normal and high-glucose) and then incubated at $37^{\circ} \mathrm{C}$ for 28 days for allowing biofilm formation on dentin. To ensure bacterial viability, fresh BHI medium was replaced every $72 \mathrm{~h}$.

Subsequently, the incubated dentin slices were washed with sterile PBS to remove unattached bacteria, immersed in the test gel, and then incubated at $37^{\circ} \mathrm{C}$. Briefly, $2 \mathrm{~mL}$ of the test solutions of different concentrations, prepared in PBS, were mixed with $0.15 \mathrm{~g}$ of carboxymethyl cellulose sodium (Aladdin Biochemical Technology Co., Ltd. Shanghai, China) to form gels. Based on the aforementioned experimental results, three concentrations $(0.04 \% \mathrm{TX}-100+60 \mathrm{mg} / \mathrm{mL}$ Met, $0.04 \% \mathrm{TX}-100+80 \mathrm{mg} / \mathrm{mL}$ Met, and $0.04 \% \mathrm{TX}-100+$ $100 \mathrm{mg} / \mathrm{mL}$ Met) with the best antimicrobial effect were used in this antimicrobial test on dentin. A gel with 2\% CHX was used as a positive control and a gel with PBS was used as a blank control. The gel treatment was performed for 7 days to simulate clinical root canal medication.

\subsubsection{E. faecalis on the Dentin Surface}

In order to evaluate the corrective effect of the gel treatment on the E. faecalis on the dentin surface, two dentin slices from each group were randomly selected for observation by field emission scanning electron microscope (FE-SEM; Ultraplus; Zeiss, Oberkochen, Germany), and six slices were washed with PBS to remove remnant gels before being transferred into $10 \mathrm{~mL}$ of fresh BHI medium (normal and high-glucose) at $37^{\circ} \mathrm{C}$. At 2, 4, 6, 8, 10, 12 , and $24 \mathrm{~h}$ after incubation, $1 \mathrm{~mL}$ of suspension was taken out for measuring absorbance at $600 \mathrm{~nm}$ with a spectrophotometer (UV-2401PC, Shimadzu Corp., Kyoto, Japan).

\subsubsection{E. faecalis in the Dentinal Tubules}

Confocal laser scanning microscope (CLSM) and CFU counting method were used to evaluate the antibacterial effect of the gel treatment on E. faecalis that invaded into the dentinal tubules. Three dentin slices selected randomly from both normal and high-glucose $\mathrm{BHI}$ were split to expose the longitudinal section of the dentinal tubules, and then was stained with LIVE/DEAD ${ }^{\circledR}$ BacLight $^{\mathrm{TM}}$ Bacterial Viability Kit (Invitrogen, Waltham, MA, USA). After that, the penetration depth of E. faecalis in the dentinal tubules was examined by an inverted Leica TCS SP8 confocal microscope (Leica Microsystems, Mannheim, Germany). Fluorescence images were analyzed with Leica confocal software LAS X (Leica Microsystems). Ten randomly selected images from each specimen were examined and the largest distance from the dentin surface to the visible bacteria was determined using the measurement function. Then, 30 quantitative data per group were collected for statistical analysis. The dentin powder samples used for CFU counting were obtained following the protocol described in previous studies [35-37] with some modifications. Three dentin slices from each group were washed with PBS and gently curetted to remove residual gel and bacteria on the surface. Then, a sterile round bur (ISO size: 012) mounted in a handpiece was used to collect dentin powder samples at low speed. Sterile forceps were used to maintain the specimens in place during sampling. The E. faecalis from the dentinal tubules were collected by centrifugation and resuspension in $1 \mathrm{~mL}$ BHI. The dentin powder samples were vigorously mixed by vortex for $20 \mathrm{~s}$ before and after incubation for $1 \mathrm{~h}$ at $37^{\circ} \mathrm{C}$, and then transferred to a $\mathrm{BHI}$ agar plate for $\mathrm{CFU}$ counting.

\subsection{In Vitro Gene Expression Assay}

Enterococcus faecalis $\left(10^{8} \mathrm{CFU} / \mathrm{mL}\right)$ treated with $0.02 \% \mathrm{TX}-100,20 \mathrm{mg} / \mathrm{mL}$ Met, or $0.02 \% \mathrm{TX}-100+20 \mathrm{mg} / \mathrm{mL}$ Met (MIC) were co-incubated at $37^{\circ} \mathrm{C}$ for $24 \mathrm{~h}$. Untreated E. faecalis was used as the blank control. RNA extraction was performed as described previously. Four milliliters of E. faecalis were harvested by centrifugation $(3000 \times g, 6 \mathrm{~min}$, $\left.4{ }^{\circ} \mathrm{C}\right)$ and then resuspended in $0.5 \mathrm{~mL}$ of lysozyme $(20 \mathrm{mg} / \mathrm{mL})$ at $37^{\circ} \mathrm{C}$ for $15 \mathrm{~min}$ to liberate the cell wall. Lysozyme was removed by centrifugation $\left(3000 \times g, 6 \mathrm{~min}, 4^{\circ} \mathrm{C}\right)$ and replaced with $1 \mathrm{~mL}$ of TRIzol Reagent (Invitrogen, Carlsbad, CA, USA), followed 
by incubation for $10 \mathrm{~min}$. The resulting solution was mixed with $200 \mu \mathrm{L}$ of chloroform, vortexed for $15 \mathrm{~s}$, and incubated for $5 \mathrm{~min}$. After centrifugation $\left(12,000 \times \mathrm{g}, 15 \mathrm{~min}, 4^{\circ} \mathrm{C}\right)$, the RNA in the aqueous phase was transferred to a new tube and mixed with an equal volume of isopropanol $\left(4^{\circ} \mathrm{C}\right)$, followed by incubation on ice for $10 \mathrm{~min}$. RNA was collected by centrifugation $\left(12,000 \times \mathrm{g}, 10 \mathrm{~min}, 4^{\circ} \mathrm{C}\right)$, washed twice with $1 \mathrm{~mL}$ of $75 \%$ ethanol $\left(4^{\circ} \mathrm{C}\right)$, and air-dried before being resuspended in $20 \mu \mathrm{L}$ of diethylpyrocarbonate (DEPC)-treated water. A UV spectrophotometer (NanoDrop, 2000; NanoDrop Technologies, Wilmington, DE, USA) was used to determine the RNA concentration and purity.

Reverse transcription was performed as described previously. One thousand nanograms of RNA from each sample was used as the template, and reverse transcription polymerase chain reaction (PCR) was performed using a Mastercycler (Eppendorf, Hamburg, Germany) with the HiScript ${ }^{\circledR}$ II Q RT SuperMix for qPCR Kit (Vazyme Biotech Co., Ltd., Nanjing, China).

Real-time quantitative PCR (RT-qPCR) was performed using the ABI QuantStudio 6 Flex (Applied Biosystems, Waltham, MA, USA) with the ChamQ Universal SYBR qPCR Master Mix Kit (Vazyme Biotech Co., Ltd., Nanjing, China). The PCR program settings were as follows: hold stage $\left(95^{\circ} \mathrm{C}\right.$ for $\left.3 \mathrm{~min}\right), \mathrm{PCR}$ stage $\left(40\right.$ cycles at $95^{\circ} \mathrm{C}$ for $10 \mathrm{~s}$ and $60{ }^{\circ} \mathrm{C}$ for $30 \mathrm{~s}$ ), and melt curve stage $\left(95^{\circ} \mathrm{C}\right.$ for $15 \mathrm{~s}, 60^{\circ} \mathrm{C}$ for $1 \mathrm{~min}$, and then $95^{\circ} \mathrm{C}$ for $15 \mathrm{~s}$ ). The primers used in this study are listed in Table 1 . To standardize the expression level of the target gene, the $16 \mathrm{~S}$ rRNA gene was selected as the housekeeping gene. TX-100 $(0.02 \%)$ and Met $(20 \mathrm{mg} / \mathrm{mL})$ were used to treat single-drug groups, and $0.02 \% \mathrm{TX}-100+20 \mathrm{mg} / \mathrm{mL}$ Met was used to treat the synergistic drug groups. Untreated E. faecalis was used as a blank control and as a baseline to compare gene expression. The raw threshold cycle $(\mathrm{Ct})$ values were calculated for relative expression using the formula $2^{-\Delta \Delta C t}$. Three independent replicate experiments were performed.

Table 1. Primer sequences used for the in vitro gene expression assay.

\begin{tabular}{|c|c|c|c|c|}
\hline \multicolumn{2}{|c|}{ Gene } & \multirow{2}{*}{$\begin{array}{c}\text { Primer Sequence } \\
\text { TCAAAGGAGAAGTTCGGGTCATTTCG }\end{array}$} & \multirow{2}{*}{$\frac{\text { Amplicon Size (bp) }}{136}$} & \multirow{2}{*}{$\begin{array}{l}\text { Reference } \\
\text { This study }\end{array}$} \\
\hline $16 S$ & $16 S f$ & & & \\
\hline & $16 S r$ & TTCTTATGCTTGCGGTGGGACTTC & & \\
\hline \multirow[t]{2}{*}{ dnaK } & $d n a K f$ & ACAGCCGGTGATAACAACCT & 152 & [38] \\
\hline & $d n a K r$ & TGGCAAGCTGATTTGTGTGC & & \\
\hline \multirow[t]{2}{*}{ groEL } & groELf & ACCTGATGAAACAGCAGCGA & 136 & [38] \\
\hline & groELr & TGCTGGAGCCAACCCATTAG & & \\
\hline \multirow[t]{2}{*}{$\operatorname{ccp} A$} & $\operatorname{ccp} A f$ & AATAAGCGCATTGACACGGC & 226 & This study \\
\hline & $\operatorname{ccp} A r$ & ATTTGGCTGATCGTGTCCGT & & \\
\hline
\end{tabular}

\subsection{Cytotoxicity Test}

To assess biocompatibility, the cell counting kit-8 (CCK-8) method was performed on MC3T3-E1 cells (ATCC). Different concentrations of test solutions, as described in Dynamic time-killing assays, were prepared and then sterilized using a $0.22-\mu \mathrm{m}$-pore-size filter unit (Merck Millipore Ltd., Darmstadt, Germany). For cell culture, $1 \times 10^{4}$ cells suspended in $100 \mu \mathrm{L} \alpha$-Modified Eagle's Medium (MEM; Thermo Scientific, Waltham, MA, USA) with $10 \%$ fetal bovine serum (FBS; Thermo Scientific) and 1\% penicillin/streptomycin (Thermo Scientific) were inoculated into each well of a 96-well plate and incubated at $37^{\circ} \mathrm{C}$ for $24 \mathrm{~h}$. Subsequently, the supernatant was replaced with $200 \mu \mathrm{L}$ of fresh normal and high-glucose Dulbecco's Modified Eagle's Medium (DMEM; HyClone, Logan, UT, USA), and $10 \mu \mathrm{L}$ of test solutions were added for another $24-\mathrm{h}$ incubation at $37^{\circ} \mathrm{C}$. Cells exposed to $2 \% \mathrm{CHX}$ were used as the positive control, non-treated cells were used as the blank control, and wells containing medium only were used as the background control. Each group included six replicate wells. The cells were washed with PBS and then incubated with $100 \mu \mathrm{L}$ of $\alpha$-MEM and $10 \mu \mathrm{L}$ of CCK-8 solution (CCK-8, Dojindo Laboratories, Kumamoto, Japan) at $37^{\circ} \mathrm{C}$ for $1.5 \mathrm{~h}$ in the dark. The absorbance was measured at $450 \mathrm{~nm}$ using a microplate reader. 


\subsection{Statistical Analysis}

GraphPad Prism 8 (San Diego, CA, USA) for Microsoft Windows was used for the statistical analysis. Data in normal distribution were analyzed using one-way analysis of variance with a Holm-Sidak's multiple comparisons test or Student's t-test. Data violating normality were analyzed using the non-parametric Kruskal-Wallis analysis with a Dunn's multiple comparisons test. The mean \pm standard error (SEM) was used for normally distributed data, while the median \pm quartile deviation (i.e., P25-P75) was used for data violating normality. Statistical significance was set at $p<0.05$.

\section{Results}

\subsection{Antibacterial Activities of TX-100, Met, and TX-100 + Met against Planktonic E. faecalis}

The MIC and $\mathrm{MBC}_{99}$ values of the different combinations of TX-100 and Met are shown in Table 2. Met exhibited antibacterial activity against E. faecalis, with the same $\mathrm{MIC}$ value in normal and high-glucose $\mathrm{BHI}$ medium. The higher $\mathrm{MBC}_{99}$ value of Met against $E$. faecalis in high-glucose $\mathrm{BHI}$ than that in normal $\mathrm{BHI}$ indicated that $E$. faecalis in high-glucose condition may be more resistant to Met. In the presence of $0.02 \%$ and $0.04 \%$ TX-100, the MIC and $\mathrm{MBC}_{99}$ values of Met were five times lower, in both normal and high-glucose conditions, demonstrating the synergistically enhanced antibacterial effect of TX-100 and Met. In addition, TX-100 showed limited antibacterial ability when used alone, as no MIC and $\mathrm{MBC}_{99}$ values could be determined.

Table 2. Minimum inhibitory concentration (MIC) and minimum bactericidal concentration (MBC99) values of Triton X-100 (TX-100) and metformin (Met) with or without TX-100 against Enterococcus faecalis (E. faecalis) in normal and high-glucose BHI.

\begin{tabular}{ccccc}
\hline Groups & \multicolumn{2}{c}{ E. faecalis in Normal BHI } & \multicolumn{2}{c}{ E. faecalis in High-Glucose BHI } \\
\cline { 2 - 5 } & MIC & MBC $_{\mathbf{9 9}}$ & MIC & - \\
TX-100 $(\% v / v)$ & - & - & 100 & 180 \\
Met $(\mathrm{mg} / \mathrm{mL})$ & 100 & 30 & 20 & 50 \\
$0.02 \%$ TX-100 + Met $(\mathrm{mg} / \mathrm{mL})$ & 20 & 30 & 20 & 40 \\
$0.04 \%$ TX-100 + Met $(\mathrm{mg} / \mathrm{mL})$ & 20 & & & \\
\hline
\end{tabular}

(-: No MIC or $\mathrm{MBC}_{99}$ could be detected.)

In the dynamic time-killing assays, similar to the blank control, the group treated with TX-100 resulted in an exponential increase in bacterial growth because of its limited antibacterial activity. The number of colonies in the Met group remained almost constant because of its limited antibacterial activity. However, the bacteria were almost eliminated after $24 \mathrm{~h}$ by the co-use of $0.02 \% \mathrm{TX}-100$ and Met, showing a statistical difference compared to the single-drug and blank control groups $(p<0.05$; Figure 1$)$. Moreover, the bacteria were almost eliminated in the first $3 \mathrm{~h}$ due to the rapid bactericidal effect of the combination of $0.04 \%$ TX-100 and Met, showing no statistical difference when compared with the $2 \%$ CHX group (Figure 1).

\subsection{Antibiofilm Activities of TX-100, Met, and TX-100 + Met against E. faecalis Biofilm}

Compared to the single-drug treatment groups, the $\mathrm{MBIC}_{50}$ values of the synergistic groups were reduced by up to 10 times in normal $\mathrm{BHI}$, and $\mathrm{MBRC}_{50}$ values were reduced by five times in both normal and high-glucose conditions (Table 3). In addition, E. faecalis biofilms seemed more robust in high-glucose $\mathrm{BHI}$ because of the higher $\mathrm{MBRC}_{50}$ values of TX-100 and Met in high-glucose condition. 
(a)

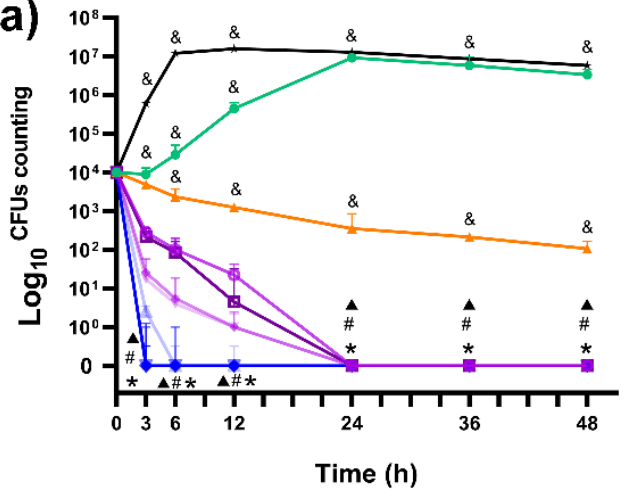

$-0.04 \% \mathrm{TX}-100$
$-100 \mathrm{mg} / \mathrm{mL}$ Met
$\rightarrow$ BLK
$\rightarrow 2 \% \mathrm{CHX}$ (b)

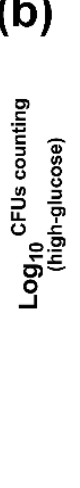

- $0.02 \% \mathrm{TX}-100+40 \mathrm{mg} / \mathrm{mL}$ Met

$\rightarrow 0.02 \%$ TX-100 + $60 \mathrm{mg} / \mathrm{mL}$ Met

- $0.02 \% \mathrm{TX}-100+80 \mathrm{mg} / \mathrm{mL}$ Met

$\rightarrow 0.02 \% \mathrm{TX}-100+100 \mathrm{mg} / \mathrm{mL}$ Met

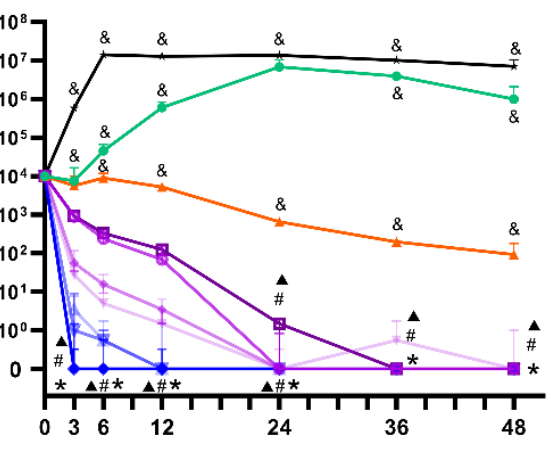

Time (h)

$\triangle \quad 0.04 \%$ TX $-100+40 \mathrm{mg} / \mathrm{mL}$ Met

$\rightarrow 0.04 \%$ TX-100 $+60 \mathrm{mg} / \mathrm{mL}$ Met

$\rightarrow 0.04 \%$ TX-100 $+80 \mathrm{mg} / \mathrm{mL}$ Met

$\rightarrow 0.04 \%$ TX-100 + $100 \mathrm{mg} / \mathrm{mL}$ Met

Figure 1. Dynamic time-killing curves. (a) in normal BHI; (b) in high-glucose BHI. (*: significant difference compared with the blank control group; $\boldsymbol{\Delta}$ : significant difference compared with the $0.04 \%$ TX-100 group; \#: significant difference compared with the $100 \mathrm{mg} / \mathrm{mL}$ Met group; \&: significant difference compared with the $2 \% \mathrm{CHX}$ group; $p<0.05)$.

Table 3. The antibiofilm activities of TX-100 and Met with or without TX-100 against E. faecalis in normal and high-glucose BHI.

\begin{tabular}{ccccc}
\hline \multirow{2}{*}{ Groups } & \multicolumn{2}{c}{ E. faecalis in Normal BHI } & \multicolumn{2}{c}{ E. faecalis in High-Glucose BHI } \\
\cline { 2 - 5 } & MBIC $_{\mathbf{5 0}}$ & MBRC $_{\mathbf{5 0}}$ & MBIC $_{\mathbf{5 0}}$ & MBRC $_{\mathbf{5 0}}$ \\
\hline $\mathrm{TX}-100(\% v / v)$ & - & - & - & - \\
Met $(\mathrm{mg} / \mathrm{mL})$ & 100 & 200 & 100 & 300 \\
$0.02 \% \mathrm{TX}-100+\mathrm{Met}(\mathrm{mg} / \mathrm{mL})$ & 40 & 40 & 40 & 20 \\
$0.04 \% \mathrm{TX}-100+$ Met $(\mathrm{mg} / \mathrm{mL})$ & 10 & 40 & 60 & \\
\hline
\end{tabular}

(-: $\mathrm{No} \mathrm{MBIC}_{50}$ or $\mathrm{MBRC}_{50}$ could be detected.)

\subsection{Antimicrobial Effect against E. faecalis on Dentin}

Similar to the blank control group, the E. faecalis bacteria on the dentin slices treated with single-drug showed an exponential growth during the 24-h incubation, exhibiting a significantly higher optical density (OD) value than the synergistic and positive control group ( $p<0.05$; Figure 2 ). The OD values of the synergistic groups treated with $0.04 \%$ TX-100+80 mg/mL Met, 0.04\% TX-100+100 mg/mL Met, or 2\% CHX showed no increase during $24 \mathrm{~h}$ of incubation in BHI (Figure 2), indicating that no live bacteria survived the 7-day treatment. Although the groups treated with $0.04 \%$ TX-100+60 mg/mL Met showed a slight increase in OD values, all synergistic groups in high-glucose BHI showed no statistical difference when compared with the 2\% CHX group (Figure 2).

The FE-SEM images confirmed the differences in the morphology of bacteria on the dentin surface among different groups (Figures 3 and 4). Extremely small perforations could be observed on the surface of E. faecalis in the $0.04 \%$ TX-100 group (Figures $3 \mathrm{~d}-\mathrm{f}$ and $4 \mathrm{~d}-\mathrm{f}$ ), while no significant change was observed in the $100 \mathrm{mg} / \mathrm{mL}$ Met group (Figures $3 \mathrm{~g}-\mathrm{i}$ and $4 \mathrm{~g}-\mathrm{i}$ ). However, the bacteria in the synergistic groups showed abnormal morphology as the cell membrane was ruptured or even dissolved with the cytoskeleton exposed (Figures 3m-o and 4m-o). Although the morphology of E. faecalis in the $2 \%$ CHX group did not change significantly (Figures $3 j-1$ and $4 j-1$ ), the experiments showed that E. faecalis was not alive (Figure 2).

In this study, the maximum tubule penetration depth of E. faecalis in normal and high-glucose BHI of the 28-day dentin slices were $159.2 \pm 21.16 \mu \mathrm{m}$ and $294.7 \pm 24.42 \mu \mathrm{m}$, examined by CLSM (Figure 5a,b). The result indicated that E. faecalis in high-glucose BHI had a greater tubule penetration depth than those in normal BHI ( $p<0.05$; Figure $5 \mathrm{c})$. The 
- Blank

$=0.04 \%$ TX- 100

$=100 \mathrm{mg} / \mathrm{mL}$ Met

$\Rightarrow 0.04 \%$ TX-100 $+60 \mathrm{mg} / \mathrm{mL}$ Met

$-\quad 0.04 \%$ TX-100 $+80 \mathrm{mg} / \mathrm{mL}$ Met

$\rightarrow 0.04 \%$ TX-100 $+100 \mathrm{mg} / \mathrm{mL}$ Met

$\rightarrow 2 \% \mathrm{CHX}$
CFU counting result of the dentin powder samples showed that there were still considerable live bacteria in dentinal tubules after 7-day gel treatment of blank control or single-drug groups. However, the live bacteria in the combination drug groups were significantly fewer than the blank control group $(p<0.05$; Figure $5 \mathrm{~d})$. There was no statistical difference between the combination drug groups and the $2 \% \mathrm{CHX}$ group (Figure $5 \mathrm{~d}$ ), and only few or no live bacteria were detected in these groups.
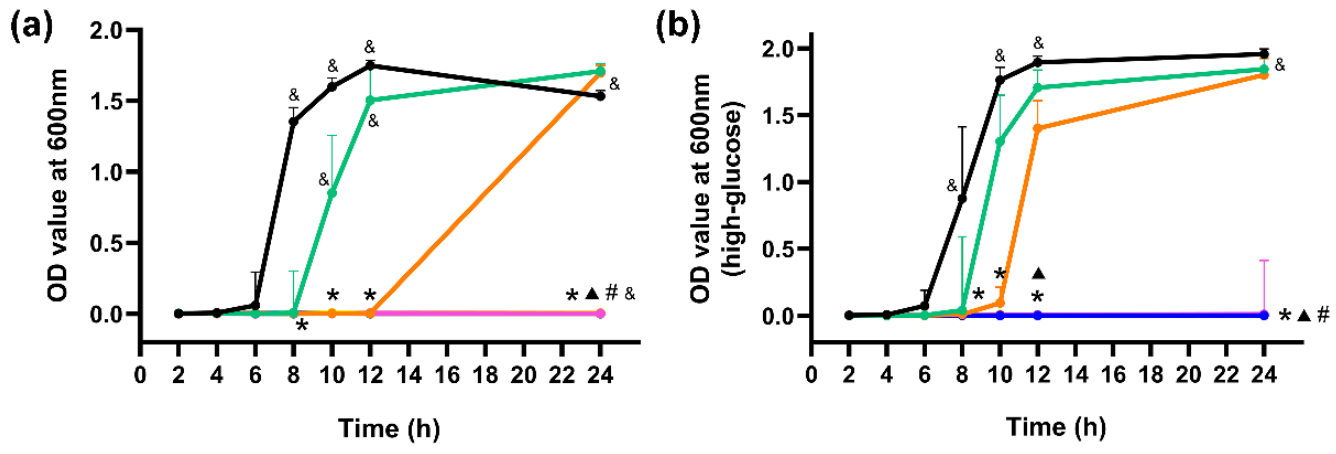

Figure 2. Growth curves of E. faecalis on dentin slices. (a) in normal BHI; (b) in high-glucose BHI. (*: significant difference compared with the blank control group; $\mathbf{\Lambda}$ : significant difference compared with the $0.04 \%$ TX-100 group; \#: significant difference compared with the $100 \mathrm{mg} / \mathrm{mL}$ Met group; \&: significant difference compared with the $2 \%$ CHX group; $p<0.05)$.
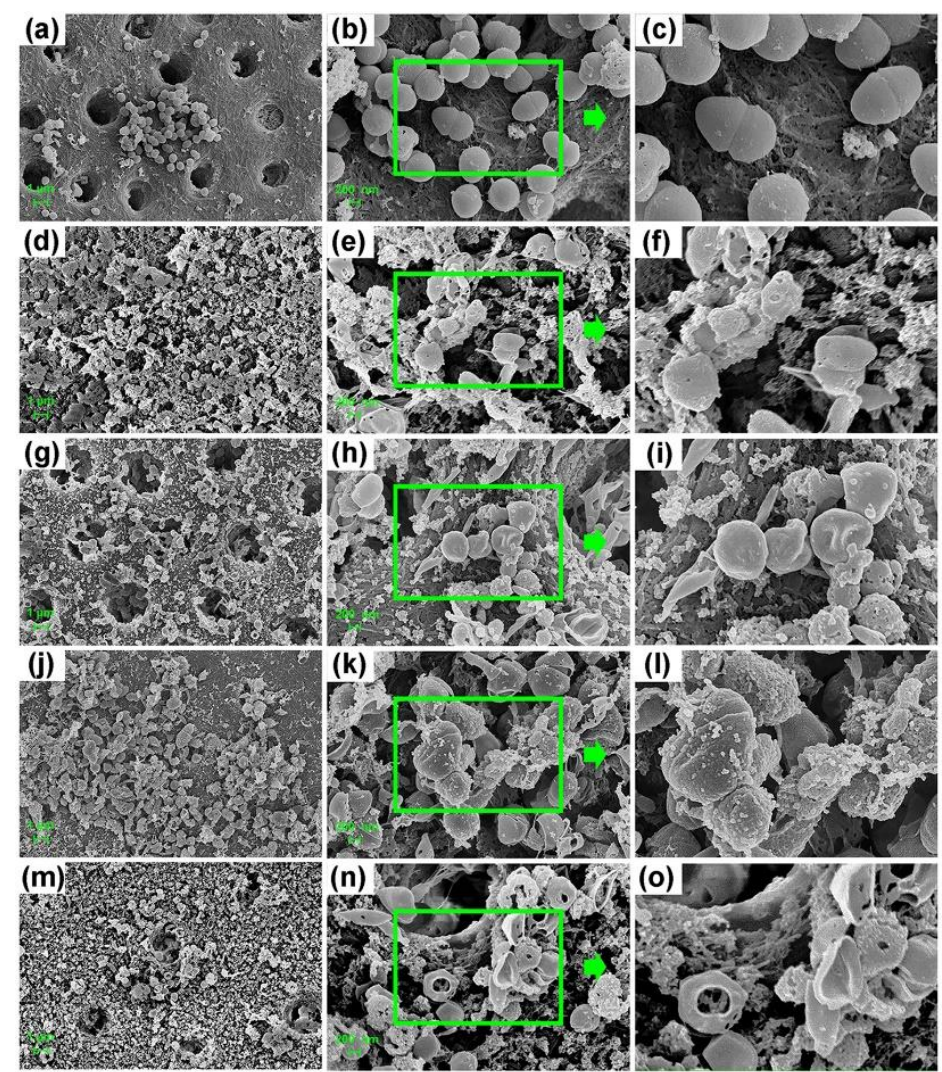

Figure 3. FE-SEM images of dentin biofilm in normal BHI. (a-c) Biofilm treated with PBS gel (blank control); (d-f) Biofilm treated with 0.04\% TX-100 gel; (g-i) Biofilm treated with $100 \mathrm{mg} / \mathrm{mL}$ Met gel; (j-1) Biofilm treated with 2\% CHX gel; (m-o) Biofilm treated with synergistic gel $(0.04 \%$ TX-100 + $100 \mathrm{mg} / \mathrm{mL}$ Met) (magnifications are $5000 \times ; 20,000 \times$; zoom in). 

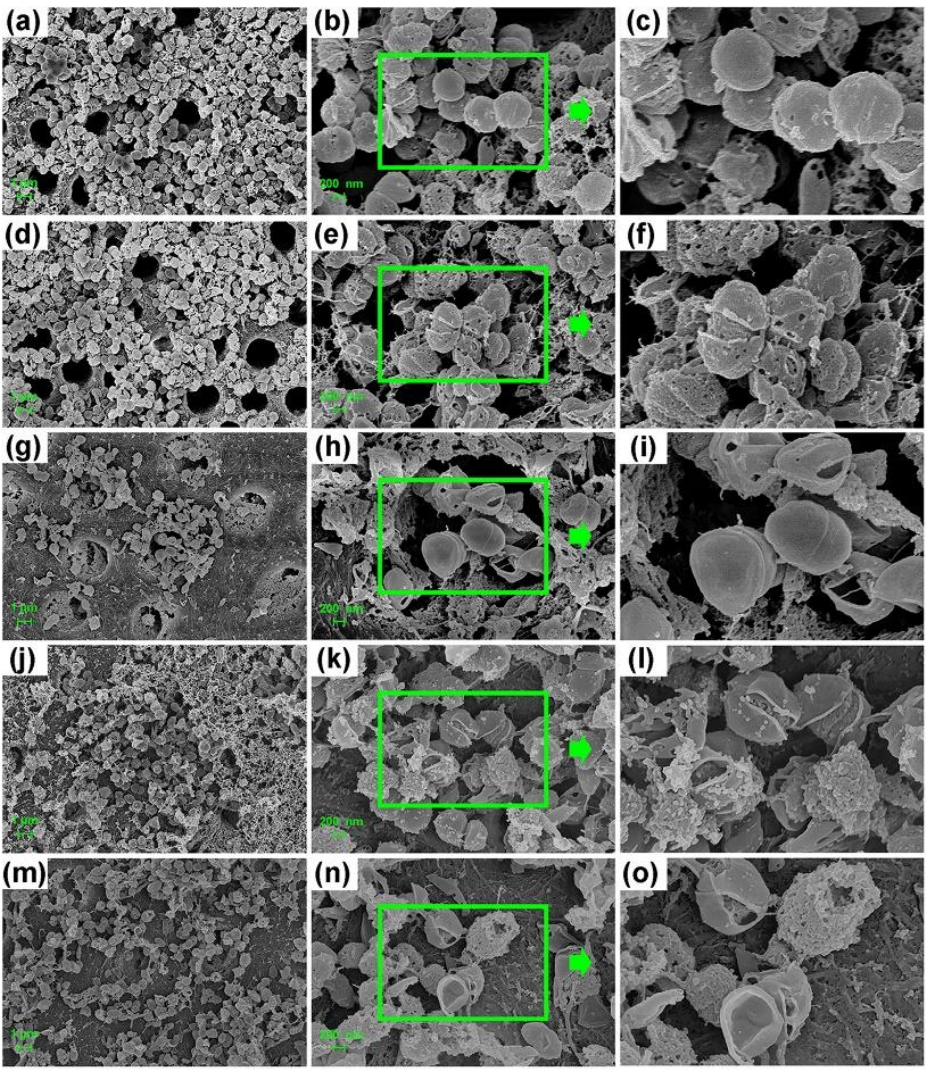

Figure 4. FE-SEM images of dentin biofilm in high-glucose BHI. (a-c) Biofilm treated with PBS gel (blank control); (d-f) Biofilm treated with 0.04\% TX-100 gel; (g-i) Biofilm treated with $100 \mathrm{mg} / \mathrm{mL}$ Met gel; (j-1) Biofilm treated with 2\% CHX gel; (m-o) Biofilm treated with synergistic gel $(0.04 \%$ TX-100 + $100 \mathrm{mg} / \mathrm{mL}$ Met) (magnifications are 5000×; 20,000×; zoom in).

(a)

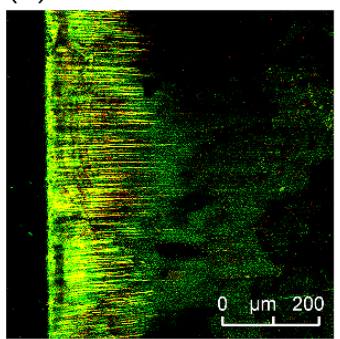

(b)

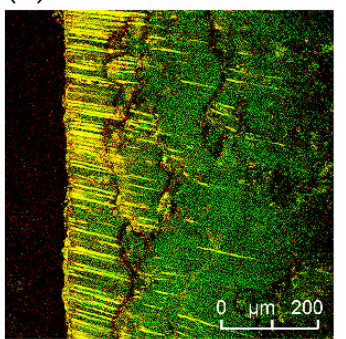

(c)

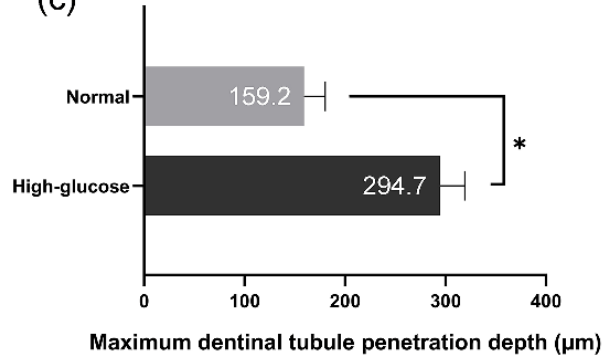

Normal BHI High-glucose BHI

(d)

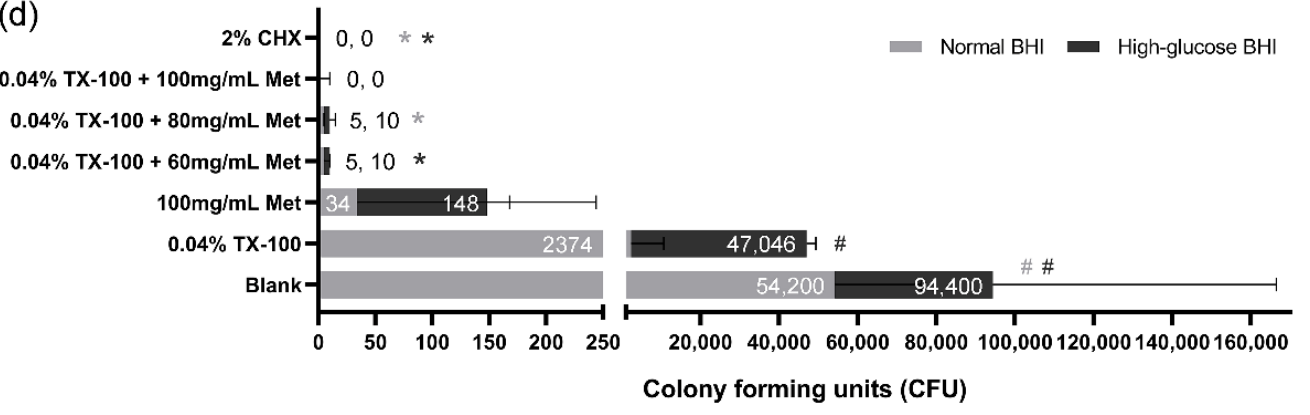

Figure 5. E. faecalis in dentinal tubules. (a,b) CLSM images $(100 \times)$ of dentinal tubule invaded by E. faecalis in normal $\mathrm{BHI}$ and high-glucose $\mathrm{BHI}$; (c) Mean tubule penetration depths of E. faecalis; (d) CFU counting of E. faecalis in dentin powder samples. (*: significant difference compared with the blank control group; \#: significant difference compared with the $2 \% \mathrm{CHX}$ group; $p<0.05$ ). 


\subsection{In Vitro Gene Expression Assay}

The expression of stress response-related genes, $\mathrm{dnaK}$, and groEL and carbon catabolite protein A (CcpA), were evaluated in this study. The results showed that the relative expression of $d n a K, g r o E L$, and ccpA in E. faecalis could be induced by TX-100 in normal BHI, and an upregulation of these genes was induced by Met in high-glucose BHI, compared to the blank control $(p<0.0001$; Figure 6$)$. However, when treated with the synergistic combination, the relative expression of the stress genes and $c c p A$ was significantly suppressed in normal BHI $(p<0.05$; Figure 6$)$.
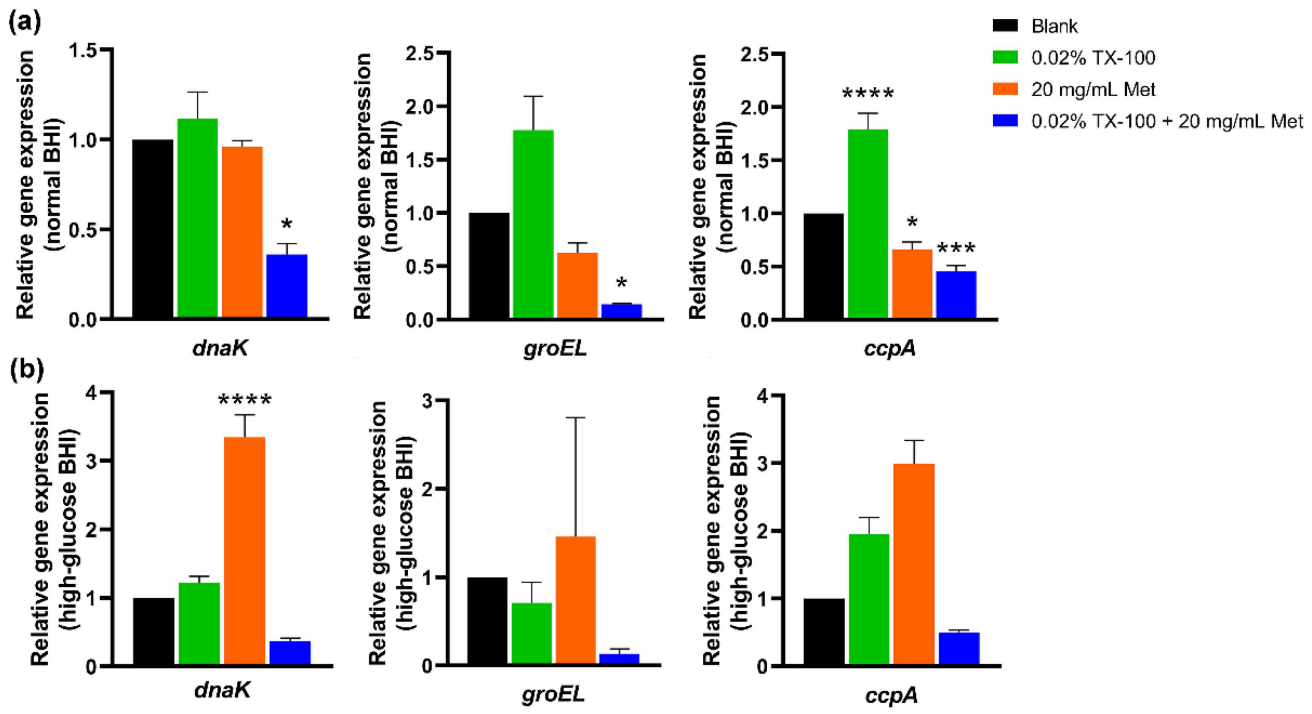

Figure 6. Relative gene expression of dnaK, groEL, and $c c p A$ in E. faecalis. (a) in normal BHI; (b) in high-glucose BHI. ( ${ }^{*}$ : significant difference compared with the blank control group; ${ }^{*} p<0.05$, $\left.{ }^{* * *} p<0.001,{ }^{* * * *} p<0.0001\right)$

\subsection{Cytotoxicity Test}

Although cell activity slightly decreased with increasing drug concentrations, no significant difference was observed between most of the synergistic groups and the blank control. In addition, the cytotoxicity of the TX-100 + Met group was significantly lower than that of the $2 \%$ CHX group in both normal and high-glucose conditions $(p<0.05$; Figure 7$)$.

(a)

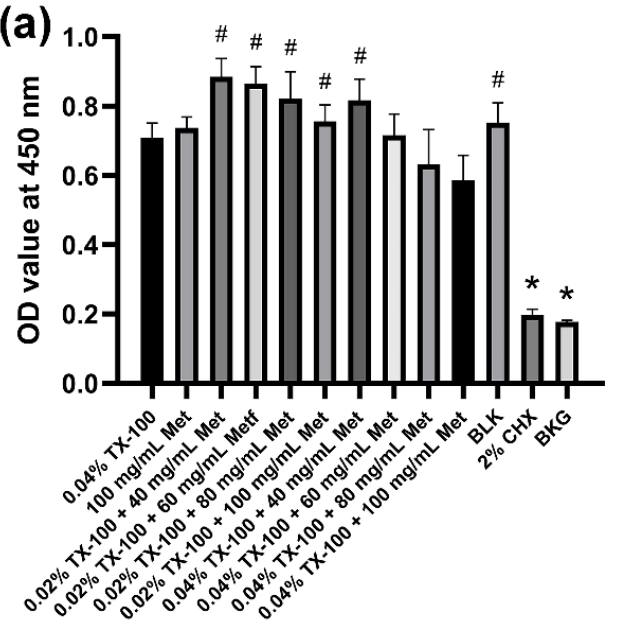

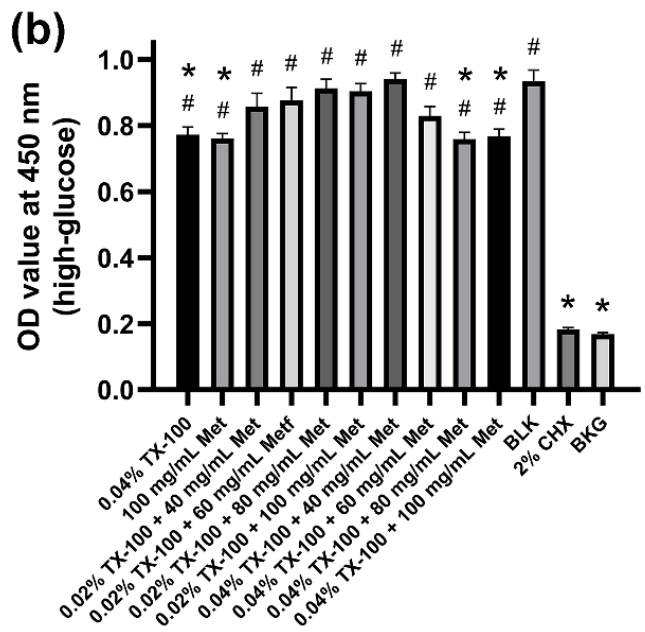

Figure 7. CCK-8 test on osteoblastic MC3T3-E1 cells. (a) in normal DMEM; (b) in high-glucose DMEM. (*: significant difference compared with the blank control group; \#: significant difference compared with the $2 \%$ CHX group; $p<0.05)$. 


\section{Discussion}

Previous studies have demonstrated a higher prevalence of periodontal and endodontic diseases [10], lower success rates of the root canal treatment [13], and slower periapical healing [12] in diabetic patients than in healthy controls. As a classical antihyperglycemic agent, Met, also shows pleiotropic effects as a clinical medicament. Studies have reported that Met can inhibit cellular inflammatory response by inhibiting the NF- $\mathrm{kB}$ signaling pathway [39], improve alveolar bone healing by increasing osteoblast differentiation in patients [40], and induce antibacterial effects against $P$. gingivalis in diabetes-related periodontitis [27]. However, there is still a lack of research on the root canal infection control in high-glucose condition, especially for E. faecalis infection. The results of this study, to our knowledge for the first time, confirmed that the antimicrobial activity of Met against $E$. faecalis could be greatly enhanced by combining it with a very low concentration of TX-100, in both normal and high-glucose conditions.

For E. faecalis in high-glucose condition, previous studies have suggested that glucose can induce and enhance the expression of enterococcal surface protein [41], eDNA, and virulence-associated genes of E. faecalis [42], which are closely related to the enhanced biofilm matrix production and pathogenicity as well as a significantly higher drug resistance rate [43]. The above results suggest that a high-glucose concentration may enhance the pathogenicity and drug resistance of bacteria and ultimately lead to the failure of a clinical antibacterial treatment for diabetes. Thus, it is of great necessity to investigate bacterial infection control in high-glucose condition.

When exposed to heat shock or other environmental stresses, the synthesis of a group of highly conserved heat shock proteins (HSPs or stress proteins) in cells rapidly increases [44]. In the general stress response of E. faecalis, HSP70/DnaK and HSP60/GroEL contribute to the refolding and degradation of denatured proteins to facilitate cell survival [45]. The transcription factor CcpA is a major regulator of genes expressed in different gram-positive bacteria. Leboeuf et al. [46] claimed that the inactivation of CcpA in E. faecalis leads to a slower growth rate and lower glycolytic capacity. Furthermore, Seidl et al. [47] pointed out that CcpA inactivation significantly reduced the drug resistance level of highly methicillin-resistant $S$. aureus. The RT-qPCR results of this study indicated that the expression of danK, groEL, and ccpA was significantly downregulated by the combination of TX-100 and Met in normal BHI. In this study, the MIC and $\mathrm{MBC}_{99}$ values of Met on E. faecalis were dramatically decreased in the presence of TX-100, displaying a higher susceptibility of E. faecalis to Met. In summary, we could surmise that by suppressing the expression of stress genes and CcpA, the combination of TX-100 and Met inhibited the stress response and glycolytic capacity of $E$. faecalis, thereby reduced their viability and proliferation and weakened their pathogenicity and drug resistance. Therefore, in the presence of TX-100, a much lower concentration of Met can still be significantly antimicrobial effective.

TX-100, usually used to solubilize proteins [48,49] or other macromolecules, can easily cross lipid bilayers and disrupt the lipid-lipid, protein-lipid, and protein-protein associations [50], thereby induce dynamic bilayer membrane perforation [51]. This mechanism increases cell membrane permeability and greatly facilitates the entry of more Met into the cell. Simultaneously, Met suppresses the glycolytic capacity and greatly blocks the energy source of bacteria by downregulating CcpA, ultimately disrupting normal physiological activity and accelerating the death process of E. faecalis. It may be another potential synergistic antimicrobial mechanism of the combination of TX-100 and Met. The FE-SEM images of the destroyed cell membrane of E. faecalis in the synergistic groups in this study confirmed the above statement.

It is worth noting that, besides the biofilm formation ability, E. faecalis also has a strong tubule invasion capacity. The depth of tubule invasion of E. faecalis in dentin biofilm model in the previous studies ranges from $156.2 \pm 25.3 \mu \mathrm{m}$ [52] to $1000 \mu \mathrm{m}$ [53]. In this study, the results of $\mathrm{CV}$ assay confirmed the antibiofilm effect of the combination drug on immature biofilm, while the FE-SEM images displayed the abnormal morphology of E. faecalis in mature dentin biofilm after 7-day gel treatment. In addition, the OD value and CFU count 
also confirmed that no E. faecalis on the dentin surface survived the gel treatment. However, this effect may be limited by the poor permeability into the dentinal tubules, as the drug gel may not reach the dentinal tubules at the optimal effective concentration. As a result, live bacteria can still be detected from the dentinal tubules, which may cause root canal reinfection. This reminds us that a gel treatment could be antimicrobial effective on the bacteria on the dentin surface, but it may be limited effective for the bacteria that invade into the dentinal tubules, especially when there is a significantly greater penetration depth of E. faecalis in high-glucose condition.

Through the above-mentioned possible mechanisms, TX-100 improved the antibacterial activity of Met and displayed a synergistic antimicrobial effect against planktonic $E$. faecalis and in vitro dentin biofilm in both normal and high-glucose conditions. However, the in-depth molecular mechanism underlying the synergistic antimicrobial effect of the combinations of TX-100 and Met still needs to be further investigated. As mentioned above, for future in vivo applications, a drug-loaded biomaterial with controlled-release profile that can penetrate into the dentinal tubules may be a promising intracanal medication, which also calls for further investigations.

\section{Conclusions}

To our knowledge, this study is the first to combine TX-100 and Met to obtain both low cytotoxicity and enhanced synergistic antimicrobial activity against $E$. faecalis in both normal and high-glucose conditions, thus providing an effective new root canal disinfectant for diabetic patients.

Author Contributions: Conceptualization, X.H., W.F. and B.F.; Methodology, X.H.; Formal analysis and investigation, X.H., S.J., W.F. and B.F.; Data curation and validation, X.H. and S.J.; Writingoriginal draft preparation, X.H., W.F. and B.F.; Writing-review and editing, X.H., W.F. and B.F.; Funding acquisition, W.F. and B.F.; Resources, W.F. and B.F.; Supervision, W.F. and B.F. All authors have read and agreed to the published version of the manuscript.

Funding: This research was funded by the National Natural Science Foundation of China (Grant Nos. 81570969 and 81771067) and the Top Youth Talent in Medicine Program of Hubei Province, China.

Institutional Review Board Statement: Not applicable.

Informed Consent Statement: Not applicable.

Data Availability Statement: All data generated or analyzed during this study are included in this published article.

Conflicts of Interest: The authors declare no conflict of interest.

\section{References}

1. De Paz, L.E.C.; Dahlén, G.; Molander, A.; Möller, Å.; Bergenholtz, G. Bacteria recovered from teeth with apical periodontitis after antimicrobial endodontic treatment. Int. Endod. J. 2003, 36, 500-508. [CrossRef]

2. Molander, A.; Reit, C.; Dahlén, G.; Kvist, T. Microbiological status of root-filled teeth with apicalperiodontitis. Int. Endod. J. 1998, 31, 1-7. [CrossRef]

3. Rôças, I.N.; Siqueira, J.F.J.; Santos, K.R. Association of Enterococcus faecalis with different forms of periradicular diseases. J. Endod. 2004, 30, 315-320. [CrossRef]

4. Siqueira, J.F.J.; Rôças, I.N. Polymerase chain reaction-based analysis of microorganisms associated with failed endodontic treatment. Oral Surg. Oral Med. Oral Pathol. Oral Radiol. Endod. 2004, 97, 85-94. [CrossRef]

5. Estrela, C.; Silva, J.A.; de Alencar, A.H.; Leles, C.R.; Decurcio, D.A. Efficacy of sodium hypochlorite and chlorhexidine against Enterococcus faecalis-A systematic review. J. Appl. Oral Sci. Rev. Fob 2008, 16, 364-368. [CrossRef] [PubMed]

6. Stuart, C.H.; Schwartz, S.A.; Beeson, T.J.; Owatz, C.B. Enterococcus faecalis: Its role in root canal treatment failure and current concepts in retreatment. J. Endod. 2006, 32, 93-98. [CrossRef] [PubMed]

7. Machado, V.; Botelho, J.; Proença, L.; Alves, R.; Oliveira, M.J.; Amaro, L.; Águas, A.; Mendes, J.J. Periodontal status, perceived stress, diabetes mellitus and oral hygiene care on quality of life: A structural equation modelling analysis. BMC Oral Health 2020, 20, 229. [CrossRef] [PubMed]

8. Cerda, J.; Vázquez de la Torre, C.; Malacara, J.M.; Nava, L.E. Periodontal disease in non-insulin dependent diabetes mellitus (NIDDM). The effect of age and time since diagnosis. J. Periodontol. 1994, 65, 991-995. [CrossRef] [PubMed] 
9. Iacopino, A.M.; Cutler, C.W. Pathophysiological Relationships Between Periodontitis and Systemic Disease: Recent Concepts Involving Serum Lipids. J. Periodontol. 2000, 71, 1375-1384. [CrossRef] [PubMed]

10. Iwama, A.; Nishigaki, N.; Nakamura, K.; Imaizumi, I.; Shibata, N.; Yamasaki, M.; Nakamura, H.; Kameyama, Y.; Kapila, Y. The effect of high sugar intake on the development of periradicular lesions in rats with type 2 diabetes. J. Dent. Res. 2003, 82, 322-325. [CrossRef]

11. Lima, S.M.F.; Grisi, D.C.; Kogawa, E.M.; Franco, O.L.; Peixoto, V.C.; Gonçalves-Júnior, J.F.; Arruda, M.P.; Rezende, T.M.B. Diabetes mellitus and inflammatory pulpal and periapical disease: A review. Int. Endod. J. 2013, 46, 700-709. [CrossRef] [PubMed]

12. Arya, S.; Duhan, J.; Tewari, S.; Sangwan, P.; Ghalaut, V.; Aggarwal, S. Healing of Apical Periodontitis after Nonsurgical Treatment in Patients with Type 2 Diabetes. J. Endod. 2017, 43, 1623-1627. [CrossRef]

13. Fouad, A.F.; Burleson, J. The effect of diabetes mellitus on endodontic treatment outcome: Data from an electronic patient record. J. Am. Dent. Assoc. 2003, 134, 43-51. [CrossRef]

14. Siqueira, J.F.J.; Rôças, I.N.; Marceliano-Alves, M.F.; Pérez, A.R.; Ricucci, D. Unprepared root canal surface areas: Causes, clinical implications, and therapeutic strategies. Braz. Oral Res. 2018, 32, e65. [CrossRef]

15. Bernardi, S.; Anderson, A.; Macchiarelli, G.; Hellwig, E.; Cieplik, F.; Vach, K.; Al-Ahmad, A. Subinhibitory antibiotic concentrations enhance biofilm formation of clinical enterococcus faecalis isolates. Antibiotics 2021, 10, 874. [CrossRef] [PubMed]

16. Neu, H.C. The crisis in antibiotic resistance. Science. 1992, 257, 1064-1073. [CrossRef]

17. Smith, R.A.; M'ikanatha, N.M.; Read, A.F. Antibiotic Resistance: A Primer and Call to Action. Health Commun. 2015, 30, 309-314. [CrossRef]

18. DeFronzo, R.A.; Goodman, A.M. Efficacy of metformin in patients with non-insulin-dependent diabetes mellitus. The Multicenter Metformin Study Group. N. Engl. J. Med. 1995, 333, 541-549. [CrossRef] [PubMed]

19. Ramachandran, A.; Snehalatha, C.; Mary, S.; Mukesh, B.; Bhaskar, A.D.; Vijay, V. The Indian Diabetes Prevention Programme shows that lifestyle modification and metformin prevent type 2 diabetes in Asian Indian subjects with impaired glucose tolerance (IDPP-1). Diabetologia 2006, 49, 289-297. [CrossRef]

20. Wang, G.; Lin, F.; Wan, Q.; Wu, J.; Luo, M. Mechanisms of action of metformin and its regulatory effect on microRNAs related to angiogenesis. Pharmacol. Res. 2021, 164, 105390. [CrossRef]

21. Malik, F.; Mehdi, S.F.; Ali, H.; Patel, P.; Basharat, A.; Kumar, A.; Ashok, F.; Stein, J.; Brima, W.; Malhotra, P.; et al. Is metformin poised for a second career as an antimicrobial? Diabetes. Metab. Res. Rev. 2018, 34, e2975. [CrossRef] [PubMed]

22. Rena, G.; Hardie, D.G.; Pearson, E.R. The mechanisms of action of metformin. Diabetologia 2017, 60, 1577-1585. [CrossRef]

23. Tahrani, A.A.; Varughese, G.I.; Scarpello, J.H.; Hanna, F.W.F. Metformin, heart failure, and lactic acidosis: Is metformin absolutely contraindicated? BMJ 2007, 335, 508-512. [CrossRef] [PubMed]

24. Elgendy, M.; Cirò, M.; Hosseini, A.; Weiszmann, J.; Mazzarella, L.; Ferrari, E.; Cazzoli, R.; Curigliano, G.; DeCensi, A.; Bonanni, B.; et al. Combination of Hypoglycemia and Metformin Impairs Tumor Metabolic Plasticity and Growth by Modulating the PP2A-GSK3ß-MCL-1 Axis. Cancer Cell 2019, 35, 798-815.e5. [CrossRef]

25. Lv, Z.; Guo, Y. Metformin and Its Benefits for Various Diseases. Front. Endocrinol. 2020, 11, 191. [CrossRef] [PubMed]

26. Drzewoski, J.; Hanefeld, M. The current and potential therapeutic use of metformin-The good old drug. Pharmaceuticals 2021, 14, 121-154. [CrossRef]

27. Khajuria, D.K.; Patil, O.N.; Karasik, D.; Razdan, R. Development and evaluation of novel biodegradable chitosan based metformin intrapocket dental film for the management of periodontitis and alveolar bone loss in a rat model. Arch. Oral Biol. 2018, 85, 120-129. [CrossRef]

28. Bai, Y.; Park, I.S.; Lee, S.J.; Bae, T.S.; Watari, F.; Uo, M.; Lee, M.H. Aqueous dispersion of surfactant-modified multiwalled carbon nanotubes and their application as an antibacterial agent. Carbon N. Y. 2011, 49, 3663-3671. [CrossRef]

29. Cho, G.; Kwon, J.; Soh, S.M.; Jang, H.; Mitchell, R.J. Sensitivity of predatory bacteria to different surfactants and their application to check bacterial predation. Appl. Microbiol. Biotechnol. 2019, 103, 8169-8178. [CrossRef]

30. Karuppiah, S.; Thangaraj, S.; Arunachalam Palaniappan, S.; Olapalayam Lakshmanan, S. Influence of surfactants on structural, morphological, optical and antibacterial properties of SnO2 nanoparticles. IET Nanobiotechnol. 2019, 13, 952-956. [CrossRef]

31. Lee, Y.S.; Lee, D.Y.; Kim, Y.B.; Lee, S.W.; Cha, S.W.; Park, H.W.; Kim, G.S.; Kwon, D.Y.; Lee, M.H.; Han, S.H. The mechanism underlying the antibacterial activity of shikonin against methicillin-resistant staphylococcus aureus. Evid. Based Complement. Altern. Med. eCAM 2015, 2015, 520578. [CrossRef] [PubMed]

32. Omri, A.; Ravaoarinoro, M.; Poisson, M. Incorporation, release and in-vitro antibacterial activity of liposomal aminoglycosides against pseudomonas aeruginosa. J. Antimicrob. Chemother. 1995, 36, 631-639. [CrossRef]

33. Richardson, K.E.; Xue, Z.; Huang, Y.; Seo, Y.; Lapitsky, Y. Physicochemical and antibacterial properties of surfactant mixtures with quaternized chitosan microgels. Carbohydr. Polym. 2013, 93, 709-717. [CrossRef] [PubMed]

34. Komatsuzawa, H.; Sugai, M.; Shirai, C.; Suzuki, J.; Hiramatsu, K.; Suginaka, H. Triton X-100 alters the resistance level of methicillin-resistant Staphylococcus aureus to oxacillin. FEMS Microbiol. Lett. 1995, 134, 209-212. [CrossRef] [PubMed]

35. Fuss, Z.; Mizrahi, A.; Lin, S.; Cherniak, O.; Weiss, E.I. A laboratory study of the effect of calcium hydroxide mixed with iodine or electrophoretically activated copper on bacterial viability in dentinal tubules. Int. Endod. J. 2002, 35, 522-526. [CrossRef] [PubMed]

36. Lin, S.; Levin, L.; Peled, M.; Weiss, E.I.; Fuss, Z. Reduction of viable bacteria in dentinal tubules treated with clindamycin or tetracycline. Oral Surg. Oral Med. Oral Pathol. Oral Radiol. Endod. 2003, 96, 751-756. [CrossRef] 
37. Gomes, B.P.F.A.; Souza, S.F.C.; Ferraz, C.C.R.; Teixeira, F.B.; Zaia, A.A.; Valdrighi, L.; Souza-Filho, F.J. Effectiveness of 2\% chlorhexidine gel and calcium hydroxide against Enterococcus faecalis in bovine root dentine in vitro. Int. Endod. J. 2003, 36, 267-275. [CrossRef] [PubMed]

38. Fan, W.; Huang, Z.; Fan, B. Effects of prolonged exposure to moderate static magnetic field and its synergistic effects with alkaline $\mathrm{pH}$ on Enterococcus faecalis. Microb. Pathog. 2018, 115, 117-122. [CrossRef]

39. Isoda, K.; Young, J.L.; Zirlik, A.; MacFarlane, L.A.; Tsuboi, N.; Gerdes, N.; Schönbeck, U.; Libby, P. Metformin inhibits proinflammatory responses and nuclear factor-кB in human vascular wall cells. Arterioscler. Thromb. Vasc. Biol. 2006, $26,611-617$. [CrossRef] [PubMed]

40. Bak, E.J.; Park, H.G.; Kim, M.; Kim, S.W.; Kim, S.; Choi, S.-H.; Cha, J.-H.; Yoo, Y.-J. The Effect of Metformin on Alveolar Bone in Ligature-Induced Periodontitis in Rats: A Pilot Study. J. Periodontol. 2010, 81, 412-419. [CrossRef]

41. Tendolkar, P.M.; Baghdayan, A.S.; Gilmore, M.S.; Shankar, N. Enterococcal surface protein, Esp, enhances biofilm formation by Enterococcus faecalis. Infect. Immun. 2004, 72, 6032-6039. [CrossRef] [PubMed]

42. Kim, M.A.; Rosa, V.; Min, K.S. Characterization of Enterococcus faecalis in different culture conditions. Sci. Rep. 2020, 10, 21867. [CrossRef]

43. Liu, Y.X.; Cao, Q.M.; Ma, B.C. Pathogens distribution and drug resistance in patients with acute cerebral infarction complicated with diabetes and nosocomial pulmonary infection. BMC Infect. Dis. 2019, 19, 603-608. [CrossRef]

44. Parsell, D.A.; Lindquist, S. The function of heat-shock proteins in stress tolerance: Degradation and reactivation of damaged proteins. Annu. Rev. Genet. 1993, 27, 437-496. [CrossRef]

45. Rince, A.; Flahaut, S.; Auffray, Y. Identification of general stress genes in Enterococcus faecalis. Int. J. Food Microbiol. 2000, 55, 87-91. [CrossRef]

46. Leboeuf, C.; Leblanc, L.; Auffray, Y.; Hartke, A. Characterization of the ccpA gene of Enterococcus faecalis: Identification of starvation-inducible proteins regulated by ccpA. J. Bacteriol. 2000, 182, 5799-5806. [CrossRef]

47. Seidl, K.; Stucki, M.; Ruegg, M.; Goerke, C.; Wolz, C.; Harris, L.; Berger-Bächi, B.; Bischoff, M. Staphylococcus aureus CcpA affects virulence determinant production and antibiotic resistance. Antimicrob. Agents Chemother. 2006, 50, 1183-1194. [CrossRef] [PubMed]

48. Bayerl, T.; Klose, G.; Blanck, J.; Ruckpaul, K. Interaction of nonionic detergents with phospholipids in hepatic microsomes at subsolubilizing concentrations as studied by 31P-NMR. Biochim. Biophys. Acta 1986, 858, 285-293. [CrossRef]

49. Schnaitman, C.A. Solubilization of the cytoplasmic membrane of Escherichia coli by Triton X-100. J. Bacteriol. 1971, 108, 545-552. [CrossRef]

50. Colavita, F.; Quartu, S.; Lalle, E.; Bordi, L.; Lapa, D.; Meschi, S.; Vulcano, A.; Toffoletti, A.; Bordi, E.; Paglia, M.G.; et al. Evaluation of the inactivation effect of Triton X-100 on Ebola virus infectivity. J. Clin. Virol. 2017, 86, 27-30. [CrossRef] [PubMed]

51. Sudbrack, T.P.; Archilha, N.L.; Itri, R.; Riske, K.A. Observing the solubilization of lipid bilayers by detergents with optical microscopy of GUVs. J. Phys. Chem. B 2011, 115, 269-277. [CrossRef] [PubMed]

52. Chivatxaranukul, P.; Dashper, S.G.; Messer, H.H. Dentinal tubule invasion and adherence by Enterococcus faecalis. Int. Endod. J. 2008, 41, 873-882. [CrossRef] [PubMed]

53. Haapasalo, M.; Ørstavik, D. In vitro Infection and Disinfection of Dentinal Tubules. J. Dent. Res. 1987, 66, 1375-1379. [CrossRef] [PubMed] 